\title{
PENDEKATAN STRATEGI INSIDE-OUT DAN OUTSIDE-IN PADA PENDIRIAN BISNIS RINTISAN ENTREPRENEUR MUDA
}

\section{Hendrik Rizqiawan}

Prodi Manajemen, Universitas Wijaya Putra hendrikrizqiawan@uwp.ac.id

\section{Iful Novianto}

Prodi Manajemen, Universitas Wijaya Putra ifulnovianto@uwp.ac.id

\section{Andi Iswoyo}

Prodi Akuntansi, Universitas Wijaya Putra andi@uwp.ac.id

\section{Yanuar Fauzuddin}

Prodi Manajemen, Universitas Wijaya Putra yanuarfauzuddin@uwp.ac.id

\begin{abstract}
The object of this study was a 25-year-old entrepreneur named Fahmi Fahrizal Pradianto. He founded and runs a culinary business in Balongpanggang District of Gresik Regency, with spicy noodle products and various other processed under the Mie Rate brand. The business that was only started for 1 year turned out to be quite successful. Evidently, although still new, Fahmi has added branches in Lamongan Regency. This approach to research uses qualitative research methods, namely through the interview process to key informants, namely Fahmi as a business owner and 2 brothers who helped him run the Mie Rate. From this study it was found that indicators in inside-out strategies include experience, capital, parental support, self-image, and desire to growth. The indicators in the outside-in strategy are the existence of market opportunities and lack of competition, the availability of supporting information and communication technology media, and the availability of suppliers.
\end{abstract}

Keywords: entrepreneur, inside-out strategy, outside-in strategy.

$\triangle$ Corresponding author:

Email Address : hendrikrizqiawan@uwp.ac.id (Surabaya, Jawa Timur)

Received 10 Januari 2022, Accepted 9 Pebruari 2022, Published 23 Pebruari 2022

\section{PENDAHULUAN}

Pandemi covid-19 yang mewabah semenjak akhir tahun 2019 lalu merupakan kejadian yang tidak diduga akan terjadi dan melanda hampir di seluruh belahan dunia. Berdasarkan data yang di informasikan oleh World Health Organization (WHO), pada bulan Maret 2021 ditemukan bahwa lebih dari 200 negara terpapar virus covid-19, termasuk juga Indonesia yang telah teridentifikasi adanya warga yang terjangkit virus covid-19 per tanggal 02 Maret 2020 (WHO, 2020). Dengan total kasus di dunia per tanggal 14 maret 2021 sebesar 119.218.587 kasus dan kasus di Indonesia sebanyak 1.414.741 kasus (WHO, 2021), tidak dipungkiri hal tersebut mengakibatkan perubahan yang masif pada berbagai aktivitas kehidupan. Dunia usaha juga terimbas cukup telak, perlahan para pengusaha yang tidak siap mulai berjatuhan, hal itu mengakibatkan banyak karyawan atau pekerja yang diberhentikan.

Badan Pusat Statistik (yang dikenal dengan BPS) Indonesia mencatat bahwa pandemi covid-19 membawa dampak yang signifikan terhadap 29,12 juta penduduk dengan usia kerja. Suhariyanto, kepala BPS Indonesia, merincikan yaitu sebanyak 2,56 juta penduduk 
diantaranya yang kehilangan pekerjaan atau menjadi pengangguran, 760 ribu warga menjadi bukan angkatan kerja, kemudian 1,77 juta masyarakat sementara tidak bekerja, serta sebanyak 24,03 juta penduduk yang masih bekerja dengan pengurangan jumlah jam kerja (Tempo.co). Di tengah segala akibat buruk dan musibah dari mewabahnya pandemi covid-19, masyarakat dituntut tetap dapat bertahan dalam menghadapinya. Bukan hanya bertahan agar kondisi tubuh tetap sehat dan tidak terpapar, namun juga bertahan dalam rangka memenuhi kebutuhan hidup.

Tentunya hal tersebut terasa berat bagi para karyawan atau pekerja yang terdampak secara langsung pandemi covid-19 dimana mereka harus diberhentikan kerja dari perusahaan mereka sebelumnya. Peran pemerintah sangat dibutuhkan pada kondisi tersebut, terlihat dengan berbagai program kebijakan pemerintah sebagai langkah konkrit menstabilkan ekonomi, pemerintah sudah berupaya semaksimal mungkin berusaha agar pandemi covid-19 tidak membawa dampak yang lebih buruk (khususnya pada sektor ekonomi) bagi masyarakat Indonesia. Para karyawan atau pekerja yang tidak lagi bekerja, dituntut berpikir lebih kreatif dan inovatif agar mendapat pemasukan guna memenuhi kebutuhan sehari-hari. Mereka dapat memanfaatkan momen tersebut dengan memulai membuka bisnis atau usaha sendiri. Terlebih, Indonesia masih memiliki persentase angka yang cukup kecil dari jumlah pengusaha yang ada. Menteri Koperasi dan Usaha Kecil Menengah (MenKop UKM), Teten Masduki, menyebutkan bahwa jumlah wirausaha Indonesia masih tertinggal jauh dengan negaranegara di Asean.

Tingkat entrepreneurship atau kewirausahaan di negara Indonesia masih lebih rendah jika dibandingkan dengan negara-negara tetangga di Asia Tenggara. Tingkat entrepreneurship negara Indonesia tercatat pada poin $3,47 \%$, berada di bawah Singapura yang hampir mencapai 9\% atau Malaysia dan Thailand yang mendekati poin 5\% (Sindonews, 2020). Objek penelitian ini adalah seorang entrepreneur yang masih relatif berusia muda, yaitu 25 tahun, bernama Fahmi Fahrizal Pradianto. Dia merupakan salah satu dari banyak pekerja atau karyawan yang terdampak pandemi covid-19, dimana yang pada akhirnya diberhentikan dari tempat bekerja. Namun
Fahmi tidak menyerah dengan keadaan, dengan pengalaman yang dia miliki selama bekerja di restoran makanan cepat saji (fast food), dia membuka sebuah bisnis yang juga bergerak di industri yang sama di Kecamatan Balongpanggang Kabupaten Gresik, yaitu industri kuliner, dengan produk mie pedas dan aneka olahan lainnya bermerek Mie Rate.

Bisnis yang baru dirintis selama 1 tahun tersebut ternyata bisa disebut cukup berhasil. Terbukti walau masih baru, Fahmi sudah menambah cabang yang berlokasi di kota lain yaitu kabupaten Lamongan. Bahkan dalam kurun waktu dekat ini dia berencana akan membuka 1 cabang lagi di kota yang lain. Omzet yang dihasilkan juga terbilang cukup besar, yaitu belasan juta rupiah bahkan pernah hingga puluhan juta per bulan. Selain mengoptimalkan pengalaman yang dimiliki, Fahmi juga memanfaatkan peran kemudahan teknologi dalam memasarkan bisnisnya, seperti mempromosikan menggunakan media sosial Instagram dan bekerja sama dengan "Go Food" dan "Grab Food".

Apa yang sudah dilakukan oleh Fahmi merupakan cerminan dari seorang pengusaha yang baik, sebagaimana definisi pengusaha yaitu orang-orang yang mempunyai kemampuan melihat dan mengumpulkan berbagai sumber daya (resources) yang dibutuhkan dalam rangka mendapatkan keuntungan, serta mampu menentukan tindakan yang tepat, guna memastikan kesuksesan (Meredith et.al. dalam Putra, 2018).

Ada dua pendekatan utama yang digunakan wirausaha untuk mencari peluang dengan mendirikan usaha baru. Pendekatan inside-out atau idea generation yaitu pendekatan yang bertumpu padaide atau gagasan sebagai faktor kunci yang menentukan keberhasilan sebuah bisnis atau usaha. Pendekatan outside-in atau opportunity recognition yaitu pendekatan yang lebih menekankan pada faktor ide atau gagasan terkait merespon kebutuhan pasar sebagai faktor kunci keberhasilan (Suryana, 2013).

Fahmi telah menggunakan strategi dengan dua pendekatan tersebut, di mana pendekatan inside-out yang berasal dari pengalamannya bekerja pada industri serupa (kuliner) dan pada pendekatan outside-in dengan memanfaatkan tren konsumen berbelanja menggunakan aplikasi pemesanan makanan online. Namun, tentunya bukan hanya 
itu saja praktek penggunaan strategi inside-out dan outside-in pada pendirian bisnis rintisan yang dilakukan oleh Fahmi pada bisnis Mie Ratenya. Oleh karena itu penelitian ini dilakukan untuk melakukan analisis yang lebih dalam terkait apa saja yang menjadi pertimbangan serta yang dapat dilakukan oleh Fahmi, baik pada pendekatan inside-out dan outside-in.

\section{Entrepreneur dan Bisnis Rintisan}

Asal kata atau istilah entrepreneur adalah entreprendre, yang merupakan bahasa Perancis dan memiliki makna yaitu memulai atau melaksanakan. Yang kemudian dimaknai menjadi melaksanakan sebuah usaha (Iswanto, 2017). Entrepreneur juga memiliki definisi yaitu pihak atau golongan masyarakat yang mengorganisasi dan menggabungkan berbagai faktor produksi lainnya untuk memproduksi barang-barang yang dibutuhkan masyarakat (Schumpeter dalam Putra, 2018). Buchari Alma (2010) mendefinisikan entrepreneur sebagai seseorang yang berusaha mempergunakan uang (harta) dan waktunya dengan menanggung segala resiko, dalam menjalankan bisnis. Ebert \& Griffin (2013) dan Boone (2013), mengidentifikasi beberapa hal yang dapat dikategorikan sebagai karakteristik atau ciri dari entrepreneur, yakni:

1. Mempunyai hasrat (keinginan) untuk selalu bertanggung jawab pada aspek bisnis dan sosial;

2. Komitmen terhadap tugas;

3. Memilih resiko yang tidak terlalu tinggi atau terlalu rendah (moderat);

4. Merahasiakan kemampuan untuk sukses;

5. Cepat melihat potensi atau peluang;

6. Orientasi terhadap masa yang akan datang;

7. Selalu melihat kembali prestasi (kinerja) masa lampau;

8. Memiliki kemampuan (skill) dalam berorganisasi;

9. Toleransi terhadap ambisi; dan

10. Fleksibilitas tinggi.

Bisnis rintisan atau startup merujuk pada sebuah bisnis atau perusahaan yang belum lama beroperasi. Perusahaan tersebut secara mayoritas atau sebagian besar merupakan perusahaan yang relatif baru berdiri dan berada padaproses pengembangan dan penelitian (observasi) untuk menemukan pangsa pasar yang sesuai atau tepat (Rejeki, 2018). Bisnis rintisan adalah suatu bisnis yang didesain untuk menciptakan suatu produk (barang atau jasa) ditengah ketidakpastian yang ekstrim (Ries, 2011). Rintisan dirancang dan diciptakan dalam rangka menemukan sebuah bentuk atau model bisnis atau usaha yang dapat berulang dan berskala (Blank, 2014). Dari definisi dan pemahaman tersebut dapat diartikan bahwa bisnis rintisan merupakan sebuah bisnis atau perusahaan yang baru dirintis atau didirikan yang dirancang untuk menemukan bentukatau model bisnis yang tepat agar dapat bertahan ditengah ketidakpastian yang ekstrem.

\section{Pendekatan Strategi Inside-out dan Outside- in}

Suryana (2013) menjelaskan bahwa pemahaman terkait pendekatan inside-out, yaitu: pendekatan berdasarkan gagasan atau ide sebagai kunci yang dapat menentukan keberhasilan sebuah bisnis atau usaha, sedangkan pendekatan outside-in yaitu pendekatan yang lebih menekankan pada faktor ide atau gagasan untuk merespon kebutuhan masyarakat (pasar) sebagai kunci kesuksesan atau keberhasilan. Pendekatan berbasis ide ini meyakini bahwa suatu perusahaan akan dapat sukses atau berhasil apabila menanggapi pasar secara responsif atau menciptakan suatu kebutuhan di pasar. Pendekatan inside-out adalah pola (model) terbaik untuk mengembangkan diri sebagai individu yang efektif.

Inside-out dalam artian mengawali sesuatu hal (diantaranya adalah melakukan perubahan) dari internal individu atau diri sendiri, tidak dari pihak luar. Bahkan lebih mendasar lagi, diawali dari bagian yang terdalam dari seseorang, baik itu pola pikir atau paradigma, karakter, maupun motif seseorang). Pendekatan ini (Inside-out) merupakan cerminan dari sikap proaktivitas, yakni merubah diri sendiri menjadi individu atau pribadi yang memiliki daya kemampuan, memiliki tanggungjawa dalam menciptakan pengaruh yang positif kepada lingkungan di sekitarnya. Begitu pula sebaliknya, tidak menunggu pihak luar (orang lain) melakukan sesuatu untuk dirinya, dimana adalah ciri dari pola yang sebaliknya yaitu: outside-in.

Pendekatan inside-out berfokus pada 
sisi diri sendiri (perusahaan) terlebih dahulu yang berarti bahwa perusahaan merancang dan membuat produk tanpa melalui observasi. Uji analisis terkait kebutuhan konsumen dan kondisi persaingan (kompetisi di pasar). Pendekatan ini mungkin dapat diterapkan jika kondisi pasar minim persaingan. Namun, pada kondisi di era pasar global di mana banyak terdapat kompetitor seperti sekarang. Selan itu, pendekatan ini dianggap sudah kurang tepat.

Pada pendekatan outside-in, pada pasar muncul kompetitor dari segala arah dan pertumbuhan ekonomi sering mengalami kontraksi atau tarik menarik. Agar dapat menghasilkan pertumbuhan (growth) bisnis yang baik dan sesuai harapan, model pendekatan inside-out dianggap cukup berisiko, lebih sesuai dan tepat jika menerapkan model pendekatan outside-in. Pendekatan ini menganjurkan untuk melihat perkembangan dan mengobservasi kondisi diluar perusahaan, kemudian perusahaan berusaha menyesuaikan diri untuk melahirkan sesuatu produk (baik barang maupun jasa), hal ini dilakukan agar perusahaan dapat bersaing dengan lebih baik (Pranjoto, 2015).

Pendekatan strategi inside-out berbicara mengenai fokus pada spesifik perusahaan sumber daya internal dan kemampuannya, dan pendekatan strategi outside-in tentang berorientasi pada pengetahuan dan sumber daya yang ada di luar perusahaan (eksternal) yang meliputi pelanggan, pemasok dan pesaing (Saeed, et. al. 2015). Strategi inside-out juga disebut sebagai resource driven yang berarti faktor pendorong berasal dari sumber daya internal perusahaan dan bagaimana kemudian pasar meresponnya. Strategi outside-in disebut pula market driven yang bermakna bahwa faktor pendorong berasal dari keinginan untuk berkompetisi mengikuti tren yang ada di pasar (Agic, et. al. 2016).

Ganter \& Hecker (2013) mengemukakan bahwa pendekatan strategi inside-out berkutat pada internal sources yang dimiliki dan dikuasai oleh perusahaan. Sedangkan Tsai, Joe, Ding, \& Lin, (2013) lebih mengedepankan pada aspek komitmen perusahaan untuk melakukan inovasi. Pada pendekatan strategi outside-in, customer orientation merupakan hal yang wajib dilakukan oleh perusahaan untuk dapat bersaing pada pasar yang ada (Hillebrand et al., 2011).
Day dan Moorman (2010) menjelaskan bahwa strategi inside-out berbicara mengenai:

1. Merancang strategi dengan melihat kondisi internal (perusahaan/bisnis).

2. Apa yang perusahaan kuasai?

3. Apa yang mampu perusahaan persembahkan /tawarkan kepada konsumen?

Sedangkan strategi outside-in terkait:

1. Merancang strategi dengan melihat kondisi pasar.

2. Melihat secara menyeluruh melalui persepsi konsumen.

3. Nilai apa yang diharapkan oleh konsumen?

Tracey et al. (2005) menyebutkan bahwa pada pendekatan outside-in, perusahaan mengeksploitasi aspek pelanggan, kompetitor dan pemasok (supplier).

\section{METODOLOGI PENELITIAN}

Pendekatan yang digunakan pada penelitian ini adalah penelitian kualitatif dimana melibatkan upaya - upaya yang vital atau penting, di mana diantaranya adalah mengajukan berbagai pertanyaan dan prosedur, mengumpulkan data yang spesifik dari para narasumber (partisipan), menganalisis data dari tema yang khusus ke tema umum (secara induktif) dan menafsirkan makna dari data yang di dapatkan. Metode penelitian kualitatif dipilih dalam penelitian ini dikarenakan dinilai dapat memberikan tingkat fleksibilitas yang lebih baik jika dibandingkan penelitian dengan pendekatan kuantitatif, dan dalam pendekatan kualitatif menawarkan kebebasan untuk mendapatkan informasi dari tangan pertama (first hand informan). Fokus penelitian ini ialah untuk mengetahui pendekatan strategi insideout dan outside-in yang sudah dilakukan oleh Fahmi pada pendirian bisnis rintisan Mie Rate; dan apa saja indikator-indikator dalam strategi inside-out dan outside-in pada pendirian bisnis rintisan Mie Rate tersebut.

\section{Lokasi Penelitian dan Teknik Pengumpulan Data}

Objek penelitian ini adalah seorang entrepreneur muda yang masih berusia 25 tahun, Fahmi Fahrizal Pradianto, dengan bisnisnya yang bernama Mie Rate. Mie Rate merupakan merek sebuah bisnis yang memiliki produk Mie Pedas Kekinian dengan berbagai level kepedasan beserta berbagai produk makanan lainnya. Mie Rate saat ini 
beroperasional di dua tempat, yaitu di Kecamatan Balongpanggang Kabupaten Gresik dan Kecamatan Mantup Kabupaten Lamongan. Penggalian dan pengumpulan data dilakukan sebanyak 3 kali interview atau wawancara kepada key informan atau narasumber kunci yaitu Fahmi Fahrizal Pradianto selaku pendiri dan pemilik Mie Rate, serta dua saudara yang membantunya, Zakiya Putri Audina yang membantu bisnis Fahmi di Balongpanggang dan Zanuar Gendut Saputro yang turut menjaga stand Mie Rate cabang Lamongan. Adapun tahapan pelaksanaan penelitiannya meliputi penyusunan instrumen penelitian beserta perlengkapan yang dibutuhkan, kemudian penggalian, pengumpulan dan analisis data, sampai penyusunan data utama hasil penelitian (analisis konten dan analisis deskriptif).

\section{HASIL DAN PEMBAHASAN}

Berdasarkan penggalian dan pengumpulan data yang telah dilakukan serta analisis data, diketahui bahwa indikator-indikator strategi inside-outdan outside-in yang digunakan dalam pendirian bisnis Mie Rate tersebut antara lain:

1. Strategi inside-out

a) Pengalaman (pengalaman kerja dan pendidikan).

Sebagaimana yang sudah dipaparkan, Fahmi adalah salah satu dari banyak pekerja atau karyawan yang terdampak pandemi covid-19, dimana yang pada akhirnya diberhentikan dari tempat bekerja. Pada saat itu dia berkarir kurang lebih selama 3 tahun di restoran makanan cepat saji (fast food).

"Saya punya basic memasak karena pengalaman kerja sebelumnya, tidak dipungkiri hal (pengalaman kerja) tersebut menjadi salah satu pemicu saya untuk mendirikan dan menjalankan Mie Rate".Fahmi, 14 Agustus 2021.

Survei yang dilakukan oleh Lambing (2000), kurang lebih di angka $43 \%$ dari responden (yang merupakan wirausahawan) memperoleh ide/gagasan bisnis dari pengalaman waktu mereka bekerja di perusahaan atau berbagai tempat profesional yang lain. Pengalaman tersebut memberikan pengetahuan dan kompetensi mengenai cara-cara menjalankan bisnis atau usaha (Widayati et al., 2019). Pengalaman bertahun-tahun bekerja di restoran makanan (industri kuliner) juga membantu Fahmi untuk dapat melayani pelanggan sebaik mungkin. Bahkan ilmunya tersebut diajarkan kepada saudara-saudaranya yang membantu menjalankan bisnis Mie Rate, salah satunya kepada Zanuar.

"Iya (saya) dilatih Pak, diajari (oleh Fahmi),,,dia ngasih contoh (juga) bagaimana melayani pembeli". Zanuar, 14 Agustus 2021.

"Dari pengalaman (kerja) dulu, saya bisa memberikan pemahaman kepada saudara yang membantu di Mie Rate, ya seperti greeting, penanganan komplain, bagaimana cara upselling". Fahmi, 14 Agustus 2021.

Memberikan pelatihan kepada pegawai merupakan langkah awal yang perlu dilakukan bagi pelaku bisnis, karena hal tersebut merupakan apa yang pegawai harapkan dalam rangka menunjang aktivitas kerja nya, terutama pada pegawai yang sering berinteraksi dengan pelanggan (Rizqiawan \& Novianto, 2021). Selain pengalaman kerja, Fahmi yang merupakan sarjana manajemen ini juga mengamini jika pengalaman akademiknya membuat dia memiliki berbagai strategi untuk menjalankan dan mengembangkan usahanya.

"Kompetensi yang saya dapatkan di bangku perkuliahan cukup penting untuk menjalankan bisnis Mie Rate, contohnya bagaimana menganalisis bisnis dan lainnya. Jika ada masalah, saya bisa buka buku waktu kuliah dulu". Fahmi, 14 Agustus 2021.

Pengalaman kerja dan tingkat pendidikan diyakini dan terbukti berpengaruh terhadap pendapat sebuah bisnis (Chiliya \& Roberts-Lombard). Tentunya hal tersebut berkontribusi terhadap eksistensi dan perkembangan bisnis atau usaha.

b) Modal (finansial, peralatan produksi, metode/resep produksi)

Ketika mendirikan bisnis Mie Rate, Fahmi mengaku tidak memiliki banyak tabungan. Dia memanfaatkan alat seadanya yang berada di rumah. Bahkan kemasan yang digunakan pada awal 
berjalannya bisnis menggunakan wadah yang terbuat dari styrofoam.

"Awal dulu tidak punya modal besar, produksi juga menggunakan seadanya alat di rumah. 2 bulan berikutnya baru beli kompor yang lebih sesuai. Kemasan juga masih (dari) styrofoam, kemudian saya ganti (wadah berbahan baku kertas) setelah pelanggan komplain karena kurang safety dan higienis". Fahmi, 14 Agustus 2021.

Fahmi juga membutuhkan beberapa waktu untuk menemukan rasa yang tepat pada produk Mie Ratenya. Mulai dari bertanya kepada teman yang bekerja di tempat makan mie pedas kekinian yang sudah populer, hingga mencari referensi lain seperti di internet. Modal bisnis atau usaha merupakan hal yang sangat dibutuhkan dalam rangka memperbesar peluang kesuksesan sebuah bisnis, besarnya modal beriringan dengan semakin besarnya peluang bisnis tersebut sukses (Arliani et al., 2019)

c) Dukungan orang tua.

Orang tua Fahmi mulanya mengharapkan dia bisa menjadi pekerja kantor atau pengajar. Sehingga kurang setuju apabila Fahmi menjalankan usaha tersebut. Namun mereka tetap mengijinkan Fahmi memulai bisnis Mie Rate, terlebih membiarkan Fahmi menggunakan peralatan memasak dan dapur untuk proses produksi. Seiring berjalannya Mie Rate, mereka kini mendukung penuh, bahkan terlibat pada proses bisnisnya. Mulai dari membeli bahan baku hingga proses produksi.

"Kalau dulu orang tua saya kurang mendukung saya jualan mie, pinginnya saya jadi kerja kantor, guru atau dosen, he, he,, he,, Sekarang, ayah \&ibu saya sangat mendukung, bahkan ikut terlibat (pada proses bisnis). Saya juga mengajak tetangga sekitar untuk membantu pengiriman pesanan ke pelanggan. Karena kadang ada pelanggan yang kurang berkenan pesan menggunakan Go Food atau Grab Food'.Fahmi, 21 Agustus 2021.

Diijinkannya Fahmi untuk memanfaatkan barang rumah dan area dapur dapat dianggap sebagai bentuk dukungan, apalagi setelah berjalannya waktu mereka juga ikut membantu menjalankan Mie Rate. Orang-orang yang berada di sekitar/terdekat (terutama orang tua atau saudara) dapat menjadi pendukung dan pemberi keyakinan dalam menjalankan sebuah bisnis (Malebana \& Swanepoel, 2015).

d) Citra diri (fisik dan komunikasi).

Fahmi masih cukup muda ketika memulai dan mendirikan Mie Rate. Dengan usia 24 tahun dan perawakan yang cukup menarik, hal tersebut menjadi faktor penarik tersendiri bagi beberapa calon pembeli dimana mayoritas mereka adalah perempuan.

"Memang (fisik Fahmi) pengaruh (memiliki pengaruh),,,yang beli kesini (Mie Rate) kan dominan perempuan, dan tahu kalau ownernya (Fahmi) ganteng. Kadang ada yang beli hanya kepingin ketemu Mas Fahmi". Zakiya, 12 September 2021.

Selain memaksimalkan citra diri fisiknya, Fahmi juga terbantu dengan cara bertuturnya yang sopan dan bagaimana dia berkomunikasi dengan baik.

"Dia (Fahmi) sopan bahasanya dan tidak pernah marah-marah (jika menghadapi pelanggan)". Zanuar, 12 September 2021.

Berlaku ramah, sopan dan komunikatif merupakan bagian dari aspek yang dapat menyebabkan pelanggan puas (Rizqiawan \& Prihantono, 2020.

e) Hasrat untuk maju.

Fahmi merupakan seorang survivor yang bisa melalui masa kritisnya pasca dirumahkan oleh perusahaan dia bekerja ketika pandemi. Bahkan sekarang menjadi hero bagi keluarganya, berhasil mendirikan sebuah bisnis dan memperoleh penghasilan yang cukup besar. Dia memulai bisnis Mie Rate dengan modal dan alat seadanya namun dengan tekad yang luar biasa. Sebagai anak pertama, Fahmi berhasil lulus kuliah dengan biaya sendiri, memanfaatkan waktu luang disela kesibukannya bekerja. Salah satu impiannya sudah tercapai, yaitu mendirikan dan menjalankan sebuah 
bisnis yang cukup menghasilkan. Namun bagi Fahmi hal tersebut masih kurang.

"Cita-cita saya, punya banyak outlet, Mie Rate bisa menguasai Pulau Jawa. Tahun depan saya berencana membuka outlet yang proper di Balongpanggang". Fahmi, 12 September 2021: "Mas Fahmi memang sering curhat ke saya kalau ingin punya banyak outlet, bisa menyaingi Mie Kober, Mie Gacoan gitu". Zakiya, 12 September 2021.

Dalam menjalankan sebuah bisnis, selain memiliki kompetensi yang tepat terkait keterampilan bisnis,(menjaga) motivasi agar bisnis berkembang dan (terus) mencari peluang merupakan hal-hal yang tidak kalah penting (Piispanen, 2017).Orang dengan hasrat yang kuat untuk sukses lebih bisa memanfaatkan peluang kewirausahaan dan berprestasi lebih baik daripada mereka yang memiliki hasrat lebih lemah (Shane and Venkataraman, 2000).

2. Strategi outside-in

a) Adanya peluang pasar dan minimnya persaingan.

Fahmi berdomisili di Kecamatan Balongpanggang Kabupaten Gresik, sekitar $30 \mathrm{~km}$ dari pusat Kabupaten Gresik. Di tempatnya tinggal, hanya ada 1 penjual produk mie pedas kekinian. Padahal berdasarkan analisis Fahmi, di tempat dia tinggal banyak yang menyukai produk tersebut. Dia kerap kali mendapati di kedai mie pedas tersebut terlihat pembeli yang mengantri.

"Setelah setengah tahun saya di rumah (menganggur tidak bekerja), saya melihat ada potensi di Balongpanggang. Padahal peminat mie pedas kekinian ini banyak, namun penjual yang saya tahu hanya 1 orang saja, akhirnya para pembeli sering antri disana”. Fahmi, 21 Agustus 2021.

Usia pelajar merupakan segmen utama dari bisnis makanan dengan produk mie pedas, seperti contohnya Kober Mie Setan (Ulfa \& Widodo, 2015). Di Kecamatan Balongpanggang sendiri, berdasarkan Badan Pusat Statistik Kabupaten Gresik tahun 2019, jumlah penduduk dengan usia pelajar yaitu rentang 15-24 tahun adalah sebanyak
8.514 orang. Tentunya merupakan angka yang cukup besar untuk dijadikan pangsa pasar utama sebuah bisnis.

b) Tersedianya media teknologi informasi dan komunikasi yang mendukung.

Tidak dipungkiri jikalau perubahan teknologi yang cepat berdampak pada banyak sektor dan aspek. Fahmi merasa sangat terbantu dengan tersedianya media teknologi informasi dan komunikasi yang mendukung bisnisnya.

"3 bulan awal berjalannya Mie Rate, saya memaksimalkan Whatsapp dan media sosial Instagram untuk mempromosikan produk-produk. Saya juga secara aktif mengajak pelanggan untuk ikut mempromosikan produk saya. Seperti program imbalan free produk (bonus) jika pelanggan memposting Ig story produk Mie Rate diInstagram mereka. Bulan ke 5 saya sudah menjadi mitra Go Food dan bulan berikutnya bergabung dengan Grab. Saya akui keberadaan mereka sangat membantu berjalannya bisnis ini, khususnya Go Food yang lebih dikenal oleh masyarakat sekitar" (Fahmi, 21 Agustus 2021).

Memasarkan produk dengan menggunakan teknologi digital (digital marketing) merupakan pilihan strategi yang dapat dipertimbangkan untuk dilakukan oleh usaha mikro agar bisnisnya bertahan, khususnya pada era pandemi (Tabroni \& Komarudin, 2021). Keputusan Fahmi memanfaatkan media sosial Instagram untuk mempromosikan produknya merupakan keputusan tepat. Keberadaan media sosial seperti Instagram dan Facebook bisa digunakan sebagai salah satu metode promosi yang efektif (Salim et al., 2020).

c) Ketersediaan pemasok.

$$
\text { Pemasok atau supplier }
$$
merupakan pihak yang vital dan sangat mendukung berlangsungnya sebuah bisnis atau usaha (Paragony et al., 2020). Terlebih pasokan bahan baku pada bisnis makanan, tidak semua pelaku bisnis mengelola perkebunan atau peternakan sendiri. Fahmi mengakui keberadaan pemasok menjadi hal yang sangat dipertimbangkan dalam mendirikan Mie Rate. Bukan saja soal harga, namun juga 
konsistensi dalam menyediakan bahan baku yang dibutuhkan.

"Bahan baku kan naik turun (harganya), sehingga harus memilihmilih supplier juga. Jadi paling tidak saya memiliki beberapa supplier agar bisa mengantisipasi kenaikan harga dan tentunya juga menjaga ketersediaan bahan baku yang kadang supplier satunya kosong atau tidak jualan".Fahmi, 12 September 2021.

\section{KESIMPULAN}

Dalam pendirian bisnis rintisan Mie Rate oleh FahmiFahrizal Pradiantoyang merupakan entrepreneur muda, ada beberapa pendekatan strategi inside-outdan outside-in yang dia gunakan secara maksimal. Strategi inside-out nya memiliki indikator antara lain pengalaman (pengalaman kerja dan pendidikan), modal (finansial, peralatan produksi, metode/resep produksi), dukungan orang tua, citra diri (fisik dan komunikasi), serta hasrat untuk maju. Adapun indikator dalam strategi outside-in adalah adanya peluang pasar dan minimnya persaingan, tersedianya media teknologi informasi dan komunikasi yang mendukung, serta ketersediaan pemasok.

\section{DAFTAR PUSTAKA}

Agic, E., Cinjarevic, M., Kurtovic, E.,\& Cicic, M. (2016). Strategic Marketing Patterns and Performance Implications. European Journal of Marketing, 50(12), 2216-2248.

Alma, B. (2010). Pengantar Bisnis. Edisi Ke 14. Bandung: Alfabeta.

Arliani, L., Indrayani, L.,\& Tripalupi, L. E. (2019). Pengaruh Perilaku Pelaku Usaha dan Modal Usaha terhadap Keberhasilan UMKMdi Desa Tukad Sumaga Kecamatan Gerokgak Kabupaten Buleleng. Jurnal Pendidikan Ekonomi, 11(2), 427-436.

Badan Pusat Statistik Kabupaten Gresik. (2019). Kecamatan Balongpanggang Dalam Angka 2019. Hal 99.

Blank, S. (2014). What's A Startup? First Principles. Nature Review Drug Discovery, 13(8).

Boone, L. E.,\& David, L. C. (2013). Contemporary Business. 15th Edition. New York: John Wiley and Sons.

Chiliya, N.,\& Roberts-Lombard, M. (2012).
Impact of Level of Education and Experience on Profitability of Small Grocery Shops in South Africa. IJBMER: International Journal of Business Management and Economic Research, 3(1), 462-470.

Day, G.S.,\& Moorman, C. (2010). Strategy from the Outside In. McGraw-Hill: Gahanna, $\mathrm{OH}$.

Ebert, R. J.,\& Ricky W. G. (2013). Business Essential. New Jersey: Prentice Hall.

Ganter, A., \& Hecker, A. (2013). Deciphering Antecedents of Organizational Innovation. Journal of Business Research, 66(5), 575-584.

Hillebrand, B., Kemp, R. G. M., \& Nijssen, E. J. (2011). Customer Orientation and Future Market Focus in NSD. Journal of Service Management, 22(1), 67-84.

Iswanto, Yun. et. al. (2017). Kewirausahaan dalam Multi Prespektif. Tangerang Selatan: Universitas Terbuka.

Malebana, M.J.,\& Swanepoel, E.(2015). Graduate Entrepreneurial Intentions in The Rural Provinces of SouthAfrica. Department of Management and Entrepreneurship. 19(1), 89-111.

Paragony, P.P., Sofitra, M.,\& Wijayanto, D. (2020). Analisis Implementasi Supplier Relationship Management pada UMKM dan Perannya Terhadap Kualitas Pemasok dan Kinerja UMKM di Indonesia. Jurnal TIN Universitas Tanjungpura, 4(2), 37-45.

Piispanen, Ville-Veikko. (2017). Entrepreneurs' Business Skills and Growth Orientation in Business Development. International Journal of Entrepreneurship and Small Business, 32(4), 515-535.

Pranjoto, R. G. H. (2015). Strategi Bisnis Ditengah Persaingan Ketat. EcoEntrepreneur - Universitas Trunojoyo Madura, 1(1). ISSN: 2502-4639.

Putra, B.P. (2018). Peningkatkan Jumlah Wirausahawan di Indonesia Melalui Kolaborasi Akademisi - Pelaku Usaha Mahasiswa. Economicus, 9(1).

Rejeki, A. (2018). Resiliensi sebagai Modal Utama Start Up Bisnis pada Era Revolusi Industry 4.0. Proceeding National Conference Psikologi UMG 2018.

Ries, E. (2011).The Lean Startup. New York: Crown Business.

Rizqiawan, H., \& Novianto, I. (2021). 
Pengembangan Indikator-Indikator Internal Marketing yang Diharapkan Internal Customer Bisnis Ritel Modern di Kota Surabaya. Jurnal Daya Saing, 7(2), 132-143.

Rizqiawan, H., \& Prihantono, D. (2020). Analisis Kualitas Layanan terhadap Kepuasan Pelanggan: Perbandingan pada Modern Retail Minimarket dengan Toko Kelontong di Kota Surabaya. Jurnal Manajerial Bisnis. 3(3): 201-210.

Saeed, S., Yousafzai, S., Paladino, A.,\& Luca, L.M.D. (2015). Inside-out and Outside-in Orientations: A Meta-Analysis of Orientation's Effects on Innovation and Firm Performance. Industrial Marketing Management, Vol. 47, 121-133.

Salim, E., Hendri, H., \& Robianto, R. (2020). Strategi Pengembangan Usaha dan Peningkatan Kinerja dalam Menghadapi Era Digital pada UMKM Café Tirtasari Kota Padang. JMM (Jurnal Masyarakat Mandiri). 4(1): 10-17.

Shane, S. \& Venkataraman, S. (2000). The Promise of Entrepreneurship as a Field ofResearch.Academy of Management Review, 25(1): 217-26.

Suryana, (2013). Kewirausahaan: Kiat dan Proses Menuju Sukses. Jakarta: Salemba Empat.

Tabroni, T., \& Komarudin, M. (2021). Strategi Promosi Produk Melalui Digital Marketing Bagi UMKM Terdampak Pandemi Covid'19 Berdasarkan Keputusan Konsumen. Jurnal Riset Entrepreneurship, 4(1), 49-57. doi:10.30587/jre.v4i1.2217

Tracey, M., Lim, J.-S., \& Vonderembse, M. A. (2005). The impact of supply-chain management capabilities onbusiness performance. Supply Chain Management: An International Journal, 10(3), 179191.https://doi.org/10.1108/13598540510 606232

Tsai, Y. H., Joe, S. W., Ding, C. G., \& Lin, C. P. (2013). Modeling Technological Innovation Performance and its Determinants: An Aspect of BuyerSeller Social Capital. Technological Forecasting and Social Change, 80(6), 1211-1221.

Ulfa, S., \& Widodo, J. (2016). Strategi Pemasaran Usaha Kuliner Kober Mie Setan Jalan Karimata No. 67 Kota
Jember. Jurnal Pendidikan Ekonomi: Jurnal Ilmiah Ilmu Pendidikan, Ilmu Ekonomi Dan Ilmu Sosial, 9(2).

Widayati, E., Yunaz, H., Rambe, T., Siregar, B.W., Fauzi, A.,\& Romli, R. (2019). Pengembangan Kewirausahaan dengan Menciptakan Wirausaha Baru dan Mandiri. Jurnal Ilmiah Manajemen Bisnis dan Inovasi Universitas Sam Ratulangi, 6(2), 98-105.

World Health Organization. (2020). Coronavirus disease 2019 (COVID-19) Situation Report - 42. In World Health Organization (Issue 42).

World Health Organization. (2021). COVID-19 Weekly Epidemiological Update.Data as received by WHO from national authorities, as of 14 March 2021, 10 am CET.

https://bisnis.tempo.co/read/1432998/pandemicovid-19-bps-catat-256-juta-orang-jadipengangguran

https://ekbis.sindonews.com/read/251008/34/ju mlah-wirausaha-kurang-banyakindonesia-belum-bisa-jadi-negara-maju1606723894 